Control \# 1427

Stewart B. Jones

Westinghouse Electric Corp/US DOE, WIPP

P.O. Box 2078, MS-195

Carlsbad, NM 88220

(505) 234-8293/FAX (505) 885-0974

\title{
PROCESSES IN THE CHARACTERIZATION, REMEDIATION, AND RECLAMATION USED TO DECOMMISSION A TAILINGS PILE CONTAINING UNKNOWN SUBSTANCES
}

\section{Description of the WIPP Project}

The Waste Isolation Pilot Plant (WIPP), located in southeastern New Mexico, is a U. S. Department of Energy (DOE) facility that is government owned and contractor operated. The Waste Isolation Division of Westinghouse Electric Corporation operates the WIPP for the DOE, Carlsbad Area Office (CAO). The mission of the CAO at WIPP is to protect human health and the environment by opening and operating the WIPP for safe disposal of transuranic (TRU) waste. This mission seeks to establish an effective system for management of TRU waste from generation to disposal. By incorporating the CAO mission, the WIPP is providing a research and development facility to demonstrate the safe disposal of TRU wastes generated by the defense activities of the U.S. Government.

\section{Introduction}

Located directly east and adjacent to the WIPP site is a saltpile (see attached photograph) encompassing a 7.5 acre area (3.04 hectares) with a depth of 27.5 feet (8.4 meters). The pile was generated during the WIPP Site Preliminary Design Validation (SPDV) program and is composed of approximately 90 percent mine tailings dispersed with a variety of mining and construction debris. During SPDV construction, the Salado, Rustler, and Dewey Lake formations were penetrated and were disposed in the saltpile. Rock units in the pile include a variety of rock types: halite, potash, anhydride, polyhalite, siltstone, sandstone, shale, gypsum, and dolomite, with halite being the largest constituent. Due to surface construction activities, clay, sand, and gravel are also expected to be found in the saltpile. Mine construction debris expected to be encountered in the pile will include the following: concrete; re-bar; plastic; electrical cable; miscellaneous pieces of worn or broken mine equipment; bolts; metal debris; and possibly hydrocarbon products/used oils in various containers.

Because the pile was not compacted during placement, hypothetically it is stratified with alternating layers of thin, compacted material over thicker layers of loose material. A thin crust, approximately six inches $(15.24 \mathrm{~cm})$ thick, has formed by the consolidation of the salt through moisture adsorption. The surface crust, however, has been penetrated by solution crevices formed within the pile along preferential drainage pathways. 


\section{DISCLAIMER}

This report was prepared as an account of work sponsored by an agency of the United States Government. Neither the United States Government nor any agency thereof, nor any of their employees, makes any warranty, express or implied, or assumes any legal liability or responsibility for the accuracy, completeness, or usefulness of any information, apparatus, product, or process disclosed, or represents that its use would not infringe privately owned rights. Reference herein to any specific commercial product, process, or service by trade name, trademark, manufacturer, or otherwise does not necessarily constitute or imply its endorsement, recommendation, or favoring by the United States Government or any agency thereof. The views and opinions of authors expressed herein do not necessarily state or reflect those of the United States Government or any agency thereof. 


\section{DISCLAIMER}

Portions of this document may be illegible in electronic image products. Images are produced from the best available original document. 
Control \# 1427

Stewart B. Jones

Westinghouse Electric Corp/US DOE, WIPP

P.O. Box 2078, MS-195

Carlsbad, NM 88220

(505) 234-8293/FAX (505) 885-0974

Targeting pockets of debris and contaminants, if present, is problematic. A grid of random drill holes on 50 foot ( 15.25 meters) centers easily misses pockets by 10 to 20 feet (3.05 6.10 meters) in diameter, and if encountered, could not assess the extent of the pile.

The variable nature of the saltpile, as well as the expected limited extent of the debris pockets, renders the prospect unlikely for adequate characterization of the saltpile based exclusively on a grid of random drill holes.

Recent technology utilizing a combination of high resolution, non-intrusive magnetic/ electromagnetic surveys (geophysical), and soil gas surveys provide a rapid, cost-effective, initial multi-phase site investigation for the location, and approximate depth of significant buried ferrous objects.

By utilizing this multi-phase approach (geophysical and soil gas survey) to characterize the saltpile, it is now possible to accurately and expeditiously characterize an area with unknown substances at minimum cost. This multi-phase technical approach will ultimately support determinations as to core drill or trench areas of concern to thoroughly characterize an area with unknown substances.

\section{Phase 1 Geophysical Survey}

A geophysical survey will be used to analyze buried objects through a combination of high resolution magnetic and electromagnetic surveys. A high resolution magnetic survey is first conducted encompassing the entire site utilizing a cesium $\left({ }^{133} \mathrm{Cs}\right)$ magnetometer. This survey provides a rapid, cost-effective initial investigation for the location and approximate depth of any buried ferrous objects of significant size.

High density magnetometer data will be accumulated at approximately one-foot intervals along parallel traverses separated by 15 feet (4.6 meters). The data grid consists of a baseline, midlines, and endlines. Data will be accumulated while traversing between the baseline and endline. This real-time data will be processed by an on-site computer graphically depicting the data recorded over the physical dimensions of the area surveyed.

Initial data analysis will be performed on-site, enabling rapid decision making. The location of buried objects will be flagged and detailed micro-site data will be provided between the traverses as needed. 
Control \# 1427

Stewart B. Jones

Westinghouse Electric Corp/US DOE, WIPP

P.O. Box 2078, MS-195

Carlsbad, NM 88220

(505) 234-8293/FAX (505) 885-0974

These initial surveys provide a reasonable assessment of areas containing buried metal under/within the saltpile. If the saltpile is totally free of metal objects, then further geophysical investigations may not be needed.

\section{Phase 2 Soil and Gas Survey}

Concurrent with the geophysical survey, the presence of volatile organic compounds (VOCs) will be evaluated through the use of PETREX passive soil gas collectors that allow for a qualitative evaluation of VOCs in the vicinity of the saltpile. The primary benefit of a passive soil gas survey is that the samplers integrate soil gas concentrations to great depths (vertical resolution to several hundred feet), while maintaining a horizontal resolution of 50 to 100 feet (15.25-30.5 meters). In order to adequately cover the saltpile surface, the samplers will be installed at 50 foot ( 15.25 meters) grid spacing. Because the samplers only require burial to a depth of 18 inches beneath ground surface, they will be easier to install than standard soil gas probes. This ease of installation will reflect a significant decrease in implementation costs while maintaining a scientifically accurate monitoring program.

The (PETREX) VOC sampling system utilizes two activated carbon-coated, stainless steel wires housed in a glass retrieval tube. The tubes will be installed approximately 18 inches beneath the surface, with the open end pointed down, allowing organic vapor to collect within the tubes. These samplers will be left in the field for a period of two weeks, and upon retrieval, will be capped and sent to the laboratory for analysis.

At the analytical lab, one wire will be analyzed from each sample by thermal desorption/mass spectrometry (TD/MS), while the second will be retained for analysis through desorption-gas chromatograph/mass spectrometer (TD-GC/MS). During the initial TD/MS analysis, the sample wire is heated with a radio frequency power super supply, and the contaminants trapped on the activated carbon are directed through a mass spectrometer. Compound identification is based on a comparison of the resulting spectra with the mass spectra of known compounds. The analysis are expressed as ion counts, which is a qualitative measure of VOC concentration.

\section{Phase 3 Detailed Characterization}

Utilizing the geophysical and soil gas surveys as an indicator, initiation of a specific location drilling program will begin (it is assumed in characterization studies of this type that there 
Control \# 1427

Stewart B. Jones

Westinghouse Electric Corp/US DOE, WIPP

P.O. Box 2078, MS-195

Carlsbad, NM 88220

(505) 234-8293/FAX (505) 885-0974

will be isolated pockets requiring enhanced characterization). This will be accomplished by collecting bore samples to determine the physical and chemical characteristics of the area of concern.

For this activity, soil samples will be collected at approximately three to six foot (1-2 meters) intervals utilizing a split-barrel type sampler (other core sampling techniques may be used) on a rig-mounted power hammer. Following retrieval from the borehole, the split-barrel sample will be covered with plastic, the sample removed, and the soil material fully described. If needed, a subsample of the material will be placed in a plastic bag for field headspace screening of VOCs using a photoionization detector. The remaining samples will be sealed to minimize the loss of VOCs from the soil sample and stored for possible submission for further laboratory analysis.

[Although not expected at WIPP, it should be noted that if a significant contaminated site is discovered, then trenching or earth moving equipment may be required to thoroughly unearth the area for characterization. If a situation of this nature occurs, field personnel must be aware of potential health hazards and don appropriate personal protective equipment during these characterization activities.]

Based on observations and field photoionization detector screening, one set of samples from what appears to be the most contaminated sample area will be submitted for laboratory analysis. In the event that contamination is not detected in the field, the sample collected from the bottom of the boring is typically analyzed. The soil samples collected during the drilling program will be analyzed for VOCs, semi-volatile organic compounds, petroleum hydrocarbons, metals, and any other chemical element of concern.

Phase 4 Reclamation/Remediation Plan

After completion of the sample data reduction and validation of data to EPA protocols for each analytical method, a characterization plan for remediation and or reclamation will be developed for each specific site. For this particular plan at WIPP there will be three alternatives:

Alternative 1 Contour the existing SPDV pile as it is and cap the entire existing pile with top soil and reclaim using indigenous vegetation.

PROCESSES IN THE CHARACTERIZATION, REMEDIATION, AND RECLAMATION USED TO DECOMMISSION A TAILINGS PILE CONTAINING UNKNOWN SUBSTANCES 
Control \# 1427

Stewart B. Jones

Westinghouse Electric Corp/US DOE, WIPP

P.O. Box 2078, MS-195

Carlsbad, NM 88220

(505) 234-8293/FAX (505) 885-0974

Alternative 2 Screen and transport only the salt materials of the SPDV pile to the main saltpile*, contour and cap the remainder of the SPDV pile with top soil, and reclaim with indigenous vegetation.

Alternative 3 Screen and transport the entire SPDV pile to the main saltpile, and reclaim the site with indigenous vegetation.

Assessment of each alternative will consider applicability based on appropriate regulations as well as the implementation cost. NOTE: For this site and many others, site regulations must be identified (EPA, U.S. Department of Interior, Bureau of Land Management, etc.), and the implementation steps to accomplish the appropriate alternative must be fully described.

\section{Conclusion}

The particular steps and processes described in this paper are innovative in that historically, when characterizing a site such as this, characterization would have been accomplished by randomly core drilling from 20 to 100 samples, and from this data the appropriate alternative would have been chosen. However, with modern nonintrusive analytical sampling techniques available, agencies will be able to generally characterize an entire site and then only specifically interrogate areas of known concern. This substantially reduces characterization costs, provides a notable time saving over historical characterization methodologies, and offers a more complete picture of the contents of the area being surveyed.

It is desirable that individuals and agencies involved with remediation sites know there are technical advancements (and more every year) incorporating cost effective and time saving methodologies that may be employed at all levels within the government and private sector infrastructure. For this site at the WIPP, a decision will be made as to which alternative to implement. For other sites there will be different alternatives, what is important is to have alternatives that incorporate contingencies relative to the type and quantity of hazardous constituents found in the area to be remediated.

* At WIPP there is another salt pile directly north of the site referred to as the main saltpile. This pile is known to contain only salt mined at the repository level, and is free of any hazardous materials.

PROCESSES IN THE CHARACTERIZATION, REMEDIATION, AND RECLAMATION USED TO DECOMMISSION A TAILINGS PILE CONTAINING UNKNOWN SUBSTANCES 
Control \# 1427

Stewart B. Jones

Westinghouse Electric Corp/US DOE, WIPP

P.O. Box 2078, MS-195

Carlsbad, NM 88220

(505) 234-8293/FAX (505) 885-0974

\section{References}

Lynn, D. C., and Jones, S. B., Environmental Monitoring and Cooperative Resource Management at the WIPP Site, Waste Management "92", Volume 1, Pages 629-632, 1992.

Daniel B. Stephens \& Associates Inc., Site Preliminary Design Validation Salt Pile Remediation/Reclamation, Technical Proposal, June 6, 1995.

Viellenave, J. H., and Hickey, J. C., Use of High Resolution Passive Soil Gas Analyses to Characterize Sites Contaminated with Unknowns, Complex Mixtures, and Semi-Volatile Organic Compounds, HMCRI's 11th Annual National Conference \& Exhibition, November 26-28, 1990.

Northeast Research Institute LLC, Proposal to Conduct a PETREX Soil Gas Survey at the Waste Isolation Pilot Plant (WIPP) SPDV Salt Pile Located in New Mexico, June 30, 1995. 


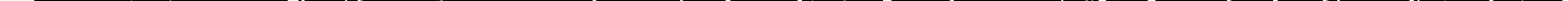

